\title{
Physician advocacy essential for Canada's First Nations
}

$\mathrm{T}$ he Government of Canada recently apologized to our First Nations' people for its residential school policy, which effectively suppressed the linguistic, cultural and spiritual practices of their pupils, with the ultimate aim of assimilation. Federal underfunding coupled with harsh discipline, exacerbated by the presence of abusive staff in some schools, also served to demoralize students and compromise their resistance to disease.

The apology has been a long time coming. A century ago, Dr. P.H. Bryce, then-chief medical officer for Canada's departments of the interior and Indian affairs (1904-1921), revealed that Aboriginal children were being decimated in his Report on the Indian Schools of Manitoba and the North West Territories. ${ }^{1} \mathrm{~A}$ few years later he made an embittered and passionate plea for restitution. ${ }^{2}$

Bryce entered public health in the decades when the science of microbiology began providing a powerful tool for monitoring environmentally caused diseases. He kept statistics on health and disease as an essential means for identifying problems and their roots, although in the residential schools he had considerable trouble obtaining accurate information. However, what he did find was that, of the 1537 pupils who attended Canada's 15 residential schools between 1883 and 1907, 7\% were in poor health and $24 \%$ died in, or shortly after leaving, the schools. The most common recorded cause of death was tuberculosis, which had emerged in all Aboriginal populations at that time; the death rate due to tuberculosis was 20 times higher in Canada's First Nation's people than among European colonists.

The government, through the minister responsible, Clifford Sifton, and his deputy, Duncan Campbell Scott, eventually acknowledged the appalling state of Indian health, but nonetheless pursued a policy of active neglect and parsimony. It may be that they thought that the Aboriginals would "go away" as forecast by Bryce's statistics, which indicated that

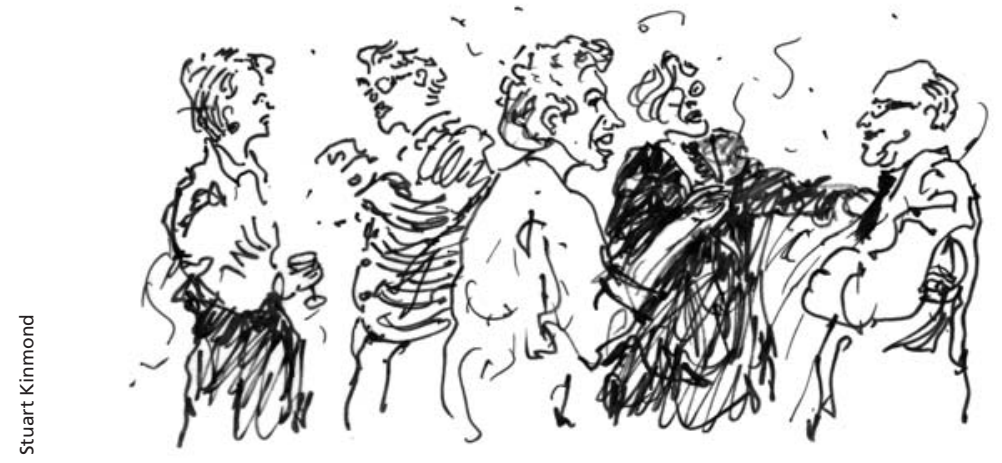

between 1904 to 1913 the Aboriginal population decreased by nearly 2000 , whereas it should have naturally increased by 20000 .

Federal responsibility for the health of Aboriginals was not acknowledged until Treaty Number Six, and then, some argue, only by the provision of a medicine chest. The appointment of Bryce did, in part, acknowledge Ottawa's duty, but his findings and crusade were not welcomed.

Because the federal government had delegated its responsibilities for Indian education to the churches, it is not surprising that in the aftermath of Bryce's report, the culpability for the conditions in the schools was shuttled back and forth between church and state. And both parties also blamed the victims, whose weak heredity or habits at home were the real cause of their misfortune. Nothing was done even when leading tuberculosis experts, including David Stewart and George Ferguson, warned that the epidemic of tuberculosis in the First Nations population threatened the health of nonAboriginal populations. Whether these physicians expressed such a fear on behalf of the latter, or were attempting to blackmail government to do something for the former, is open to question. Physicians may well have used this political ploy to get help for the disadvantaged.

We could use a Bryce today. As noted by epidemiologist Geoffrey Rose, "The primary determinants of disease are mainly economic and social, and therefore its remedies must also be economic and social. Medicine and politics cannot and should not be kept apart."'3
The specific problems of 100 years ago have changed, but the underlying determinants have not. When Save the Children, an esteeemed nongovernmental organization, describes Canada's North as "the slowest evolved disaster that I've ever worked in,"4 something must be done. Physicians have a distinct role, for as Virchow, a model for mixing science and political service, said, "The physicians are the natural attorneys of the poor and the social problems should largely be solved by them."

\section{Peter Warren MB B Chir Winnipeg, Man.}

\section{REFERENCES}

1. Bryce PH. Report on the Indian schools of Manitoba and the North-West Territories Ottawa: Government Printing Bureau; 1907.

2. Bryce PH. The story of a national crime: being an appeal for justice to the Indians of Canada; the wards of the nation, our allies in the Revolutionary War, our brothers-in-arms in the Great War. Ottawa: J. Hope; 1922.

3. Rose G. The strategy of preventive medicine. Oxford (UK): Oxford University Press; 1992

4. Silversides A. The North like "Darfur." CMAJ 2007;177:1013-4.

5. Ackerknecht EH. Rudolf Virchow: doctor, statesman, anthropologist. Madison (WI): University of Wisconsin Press; 1953

A retired specialist in internal medicine and respirology, Dr. Warren is enrolled in the joint master's program in history at the Universities of Manitoba and Winnipeg.

Have you got an opinion about this article? Post your views at www.cmaj.ca. Potential Salon contributors are welcome to send a query to salon@cma.ca. 